\title{
Metody dokumentace místa dopravní nehody
}

\author{
Methods of Documentation Traffic Accident Site \\ Jakub Motl $^{\mathrm{a}^{*}}$, Jan Rücker ${ }^{\mathrm{a}}$, Jitka Kafoňkováa ${ }^{\mathrm{a}}$, Albert Bradáč ${ }^{\mathrm{b}}$ \\ ${ }^{a}$ Centrum dopravního výzkumu, Brno \\ bysoké učení technické v Brně, Ústav soudního inženýrství, Brno
}

\begin{abstract}
Abstrakt
Př́íspěvek se zabývá srovnáním běžně dostupných metod s metodami méně obvyklými, které lze využít při dokumentaci místa dopravní nehody. Přesné a kvalitní provedení dokumentace místa dopravní nehody, zejména ve formě plánku, je jedním z důležitých údajů pro následnou analýzu nehodového děje. $V$ př́spěvku jsou porovnány metody zaměření pomoci měřicího kolečka, totální geodetickou stanicí, GNSS stanicí, rektifikací fotografie a 3D scannerem.
\end{abstract}

Klíčová slova: plánek místa dopravní nehody, fotodokumentace, polygon, 3D scanner, totální stanice, kvadrokoptéra.

\section{1. ÚVOD}

V soudně znalecké praxi je pro korektní posouzení dopravní nehody důležité mít dostatek kvalitních a exaktních podkladů. Mezi základní podklady patří fotografie, výpovědi účastníků, případně svědků dopravní nehody a plánek místa dopravní nehody. Správná a důkladná dokumentace stop vyžaduje jisté odborné znalosti a pečlivost. Mezi nejdůležitější podklady patř́i zejména podrobná fotodokumentace a přesný plánek místa dopravní nehody. V minulosti, ale i v současné době je v Česku nejrozšířenějšś způsob zaměření místa dopravní nehody pravoúhlou metodou pomocí pásma a měřícího kolečka. Jedná se o relativně jednoduchý a levný způsob měření.

\section{METODY DOKUMENTACE MÍSTA DOPRAVNÍ NEHODY}

Zaměření místa dopravní nehody patří mezi nejnáročnější činnosti prováděné na místě dopravní nehody a jeho správné provedení je

\begin{abstract}
The paper deals with a comparison of commercially available methods with less usual methods that can be used when documenting the location of traffic accidents. Precision and quality design documentation location of traffic accidents, especially in the form of the plan, is one of the important data for subsequent analysis of accident. The paper compared methods of focus by measuring wheels, geodesic total station, GNSS station, photographs and 3D scanners.
\end{abstract}

Keywords: map of the location of traffic accidents, photographs, polygon, 3D scanner, total station, quadcopter.

velmi důležité. Neúplné, případně špatné zaměření místa dopravní nehody může negativně ovlivnit možné další znalecké zkoumání. Pro zaměření místa dopravní nehody se $\mathrm{v}$ zásadě používají tř̌i základní metody vyměřování:

- metoda pravoúhlého měření,

- metoda trojúhelníkového měření,

- metoda průsečíková,

- geodetické zaměření,

- 3D skenování.

Volba metody měření je závislá na konkrétním tvaru komunikace a poloze vozidel na místě dopravní nehody. Je možné, a v některých př́padech vhodné, metody vzájemně kombinovat. [1]

\subsection{Metoda pravoúhlého měření (ortogonální metoda)}

Při této metodě se jednotlivé body zaměřují pravoúhlými souřadnicemi - staničením a kolmicí k měřické přímce. Staničení je délka měřná od stanoveného bodu, výchozího bodu měření (dále VBM) po měřické přímce, kolmice je délka kolmá $\mathrm{k}$ měřické přímce měřená mezi měřickou přímkou a určovaným bodem. $\mathrm{K}$ zaměření 

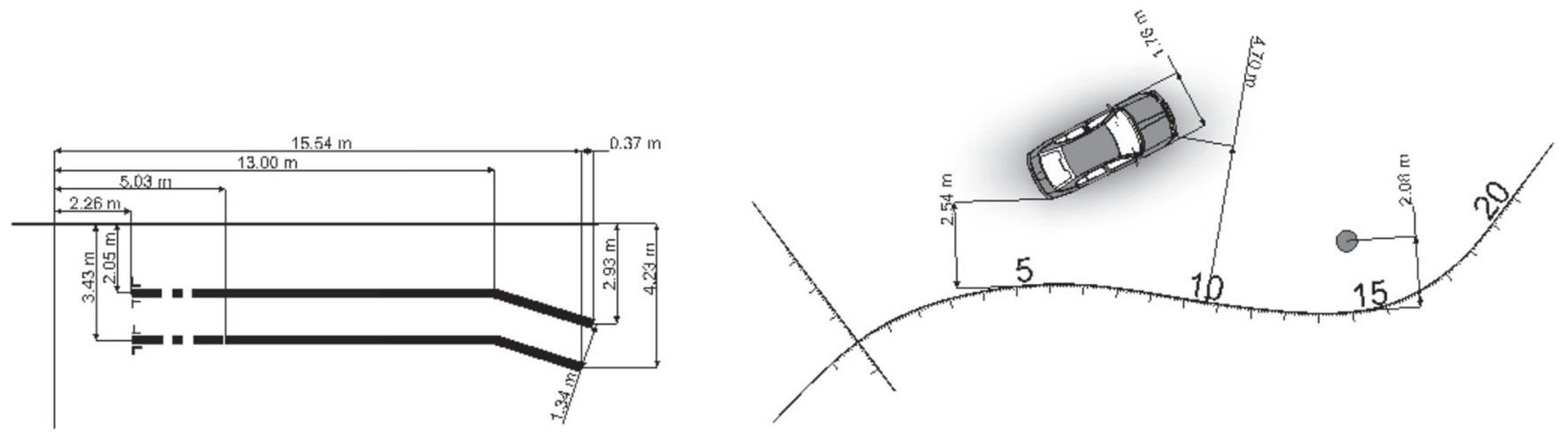

Obr. 1 Pravoúhlé měření [10].

Fig. 1 Rectangular measurement [10].

je možné použít pevnou (je připojena na body ležící na této měřické přímce) nebo volnou měřickou př́ímku (je připojena na body ležící mimo tuto měřickou přímku).

Při měření touto metodou je měřený prostor označen nejméně dvěma body (podle složitosti), které se propojí př́mkou. Tato metoda je velmi vhodná pro krátké, rovné úseky míst dopravních nehod. Její využití však není vyloučeno ani v prŕpadě zaměření místa dopravní nehody v oblouku. Policií České Republiky je tento způsob zaměření využíán nejčastěji. Př́iklad využití ortogonální metody je zobrazen na obr. 1. [1]

\subsection{Metoda trojúhelníkového měření}

Prostor, který je potřeba změřit, se pomyslně pokryje sítí trojúhelníků a všechny délky, které takto vzniknou, se změří. Je nutné důsledné značení všech vzdáleností, aby se předešlo zmatku v měření. Trojúhelníky jsou konstruovány pomocí tři stran (konstrukce trojúhelníkové sítě pomocí měření úhlů mezi jeho stranami se v praxi kvůli náročnosti nevyužívá). Trojúhelníková metoda je vhodným měřením pro zaměření členitých komunikací nebo křižovatek. Způsob využití trojúhelníkové metody popisuje
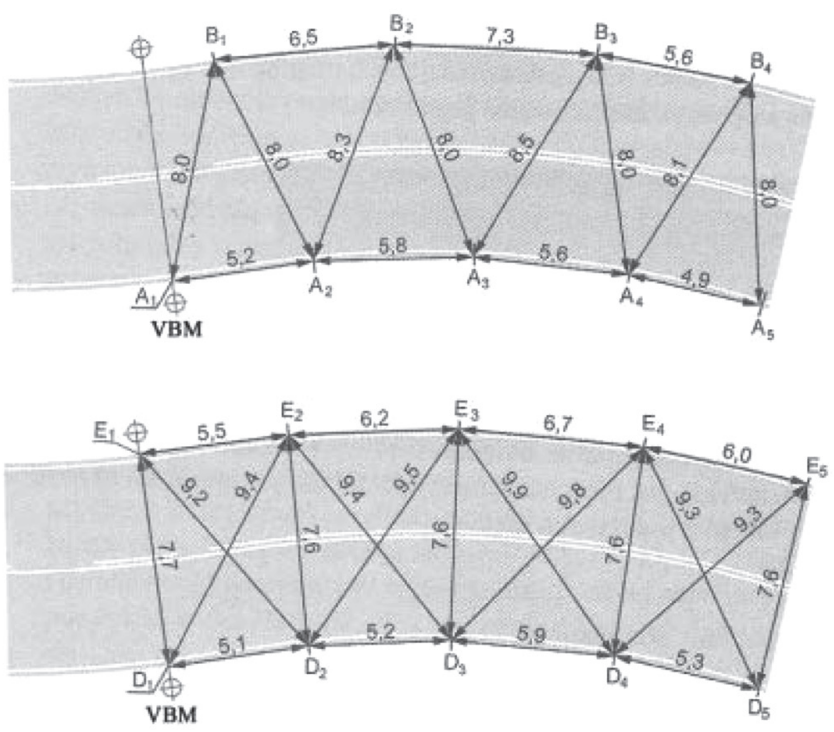

Obr. 2 Trojúhelniková metoda [1].

Fig. 2 Triangular method [1]. obr. 2. Na obr. 3 a obr. 4 je pak patrný postup při zaměřování stop na komunikaci. [1]

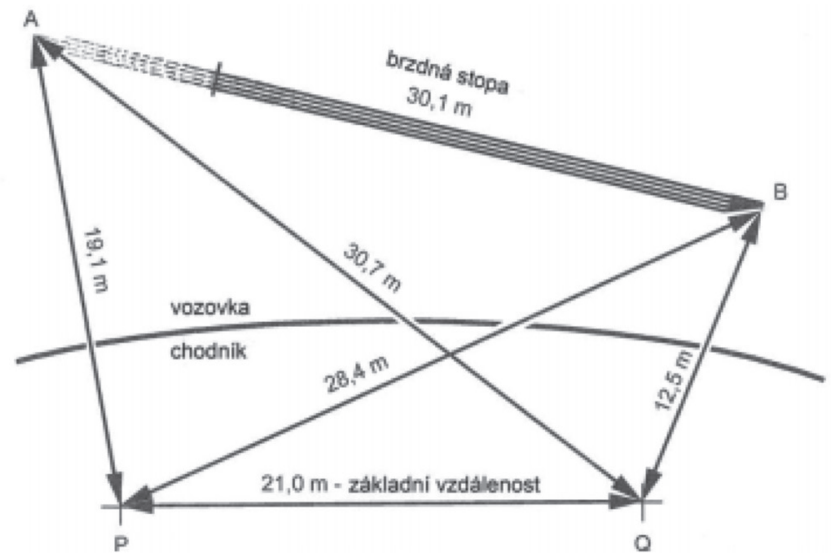

Obr. 3 Trojúhelníková metoda [1].

Fig. 3 Triangular method [1].
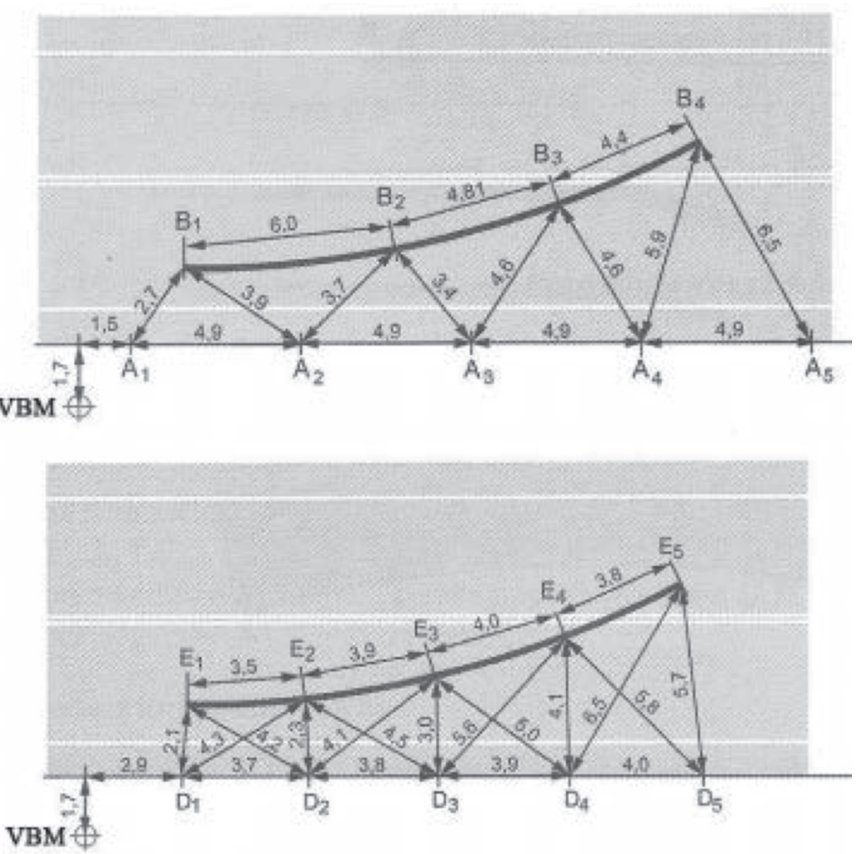

Obr. 4 Trojúhelníková metoda [1].

Fig. 4 Triangular method [1]. 
Nevýhodou této metody je její citlivost na jednotlivé změřené vzdálenosti. $\mathrm{V}$ případě jedné chybně změřené vzdálenosti je pak ovlivněn celý tvar měřeného úseku.

\subsection{Metoda průsečíková}

Je třeba určit výchozího bod měření a dále pevné body P1 a P2, od kterých se měří vzdálenost k požadovaným objektům. Mezi výchozím bodem měření a pevným bodem $\mathrm{P} 1$ a dále mezi výchozím bodem měření a pevným bodem $\mathrm{P} 2$ se změří vzdálenosti. Následně se měří vzdálenost mezi zaměřovaným bodem $\mathrm{B}$ a body P1 a P2. Pro následnou konstrukci plánku je potřeba vykreslit kružnici o poloměru P1-B a P2-B, kdy průsečík těchto kružnic by se měl pohybovat $\mathrm{v}$ rozmezí úhlu $45^{\circ}-135^{\circ}$. Pokud jsou průsečíky ve zvoleném rozsahu úhlů, jsou pevné body P1 a P2 zvoleny vhodně. Ukázka průsečíkového měření je uvedena na obr. 5. [1]

Výhodou proti trojúhelníkové metodě je nezávislost zaměřených bodů navzájem. Tedy nesprávné zaměření jednoho neovlivní správnost polohy ostatních.

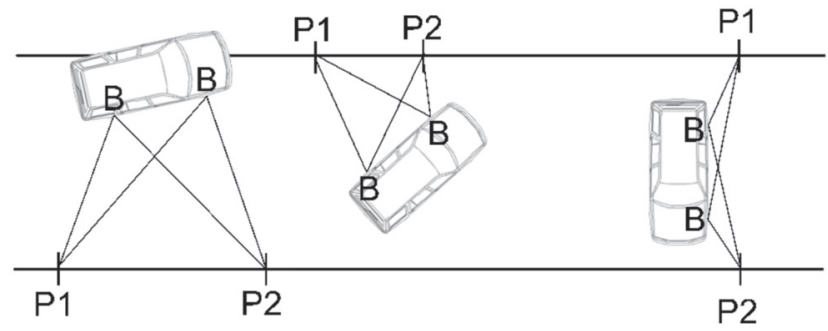

Obr. 5 Metoda průsečíkového měrení [10].

Fig. 5 The method of intersection measurement [10].

\subsection{Geodetické zaměření}

Jedná se o zaměření s pomocí některého z geodetických přístrojů, kdy výsledkem jsou sférické, popř. již rovnou pravoúhlé, souřadnice každého bodu. Body jsou měřeny nezávisle na sobě, měření je dle použitého přístroje rychlé a přesné. $\mathrm{K}$ jednotlivým př́istrojům viz dále.

\subsection{D skenování}

Jedná se o nejmodernější metodu, jejímž výsledkem je přesný 3D tvar celého prostoru a jednotlivých objektů. Tvar může být tvořen mračnem bodů (body je možné také obarvit), nebo po úpravě plochami (pro tvorbu ploch se využívá trojúhelníková metoda).

\section{PŘÍSTROJE A ZAŘÍZENÍ PRO DOKUMENTACI MÍSTA DOPRAVNÍ NEHODY}

\subsection{Měřičské kolečko, pásmo, laserový dálkoměr}

Měřící kolečko a pásmo jsou základními nástroji pro měření vzdálenosti při zaznamenávání místa nehody. Jsou stejné, jaké používá napřr. Policie ČR. Přesnost měření je dostačující. Jejich hlavní výhodou je rychlost měření a operativnost především za situace, kdy k měření dochází na nepřehledných místech a mnohdy i při neomezeném silničním provozu. Spolu s digitální vodováhou jsou měřičské kolečko a pásmo základními a naprosto nezbytnými pomůckami pro zaměření místa dopravní nehody.
Tato trojice pomůcek umožňuje jak polohová, tak výšková měření (napřr. sklony vozovek, svahu, př́íkopu apod.). Pásmo a kolečko lze nahradit laserovým dálkoměrem, což eliminuje pohyb po vozovce, ale pro měření jsou potřeba dvě osoby.

\subsection{Teodolit}

Pro geodetické zamření lze použít i teodolit (slouží k měření vodorovného a svislého úhlu) a vzdálenosti lze doměřit některou z výše uvedených pomůcek. Výsledkem jsou pak sférické sourradnice, které lze přepočítat na pravoúhlé.

\subsection{Tachymetry}

Tachymetr je př́stroj, který kombinuje funkce teodolitu a měřiče vzdálenosti. S pomocí rozděleného obrazu, kdy každá část je do okuláru lomena pod jiným úhlem, lze určit vzdálenost hledaného bodu. Výsledkem jsou tedy opět sférické souřadnice. Tachymetry umí rovněž mechanicky redukovat měřenou vzdálenost na její průmět do vodorovné roviny (tzv. autoredukční tachymetr).

\subsection{Geodetická totální stanice}

Geodetické totální stanice jsou zeměměřické př́stroje, které slouží k měření a vytyčování vodorovných a svislých úhlů, délek a k registraci naměřených dat s možností matematických operací s těmito daty. Totální stanice vznikla spojením teodolitu, elektrooptického laserového dálkoměru a jednoúčelového počítače do jednoho celku. Úhlové a délkové hodnoty lze odečítat prrímo na displeji z tekutých krystalů a zároveň je zde možnost registrovat je ve vnitřní paměti prŕístroje a eventuálně provádět i matematické operace s nimi (např. převod šikmé délky na vodorovnou, převod polárních souřadnic na pravoúhlé, výpočet převýšení atd.). [8]

Pomocí totální stanice můžeme řešit i některé další geodetické úlohy, napřr. určování výměr z měřených lomových bodů pozemku, určení nepř́istupné výšky atd. Stanice současně umožňuje ze zadaných hodnot pravoúhlých souřadnic (přenesených do totální stanice $z$ počítače nebo zadaných manuálně) vytyčit podrobné body $\mathrm{v}$ terénu ze známého bodu. Data lze přenášet $\mathrm{v}$ běžně použivaných formátech a následně zpracovávat Množství geodetických úloh, které lze totální stanicí řešit, je závislé na použitém modelu př́stroje a ovlivňuje jeho cenu. [2]

Zaškolení na používání totální stanice není časově náročné ani obtížné. Při měření vzdálenosti se laserový paprsek odráží bud'

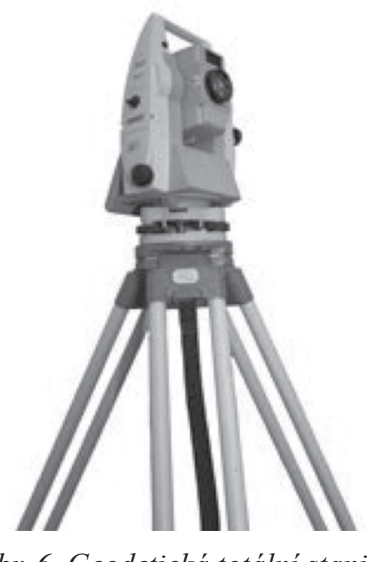

Obr. 6 Geodetická totální stanice.

Fig. 6 Geodetic Total Station. 


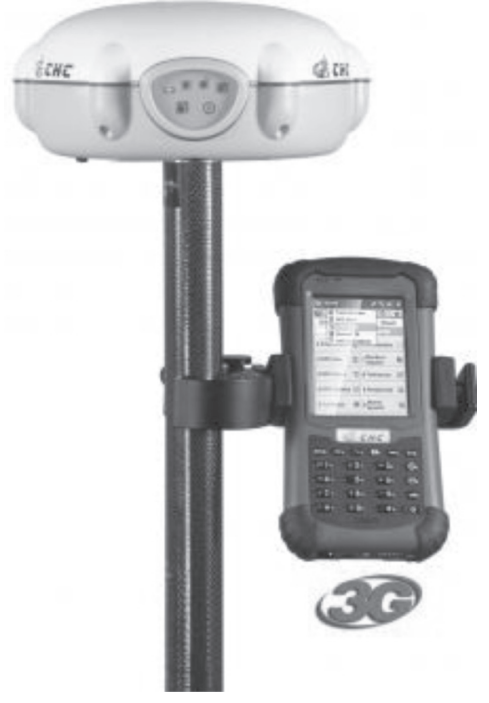

Obr. 7 GNSS přijímač.

Fig. 7 GNSS receiver.

od povrchu měřeného objektu (limitováno použitým př́strojem, vzdáleností, úhlem plochy povrchu), nebo od tzv. koutového odražeče-jedná se o tři zrcadla, která jsou vzájemně v pravém úhlu. Paprsek se tak odrazí vždy ve stejném směru, odkud na odražeč dopadá. [7]

\subsection{GNSS Přijímač}

GPS - globální polohové systémy z anglického Global Positioning Systems (obr. 7) jsou z geodetického hlediska jednou z metod kosmické geodezie. Z hlediska rozšíření v geodetické praxi patři k nejužívanějším metodám kosmické geodezie. GPS je družicový systém, který poskytuje přesné informace o poloze, rychlosti a čase v jednotném referenčním systému na kterémkoli místě na Zemi. Globálních polohových systémů byla vyvinuta celá řada např.:

- TRANSIT (vojenské námořnictvo USA),

- GLONASS (Rusko),

- NAVSTAR GPS (USA),

- galileo (EU),

- COMPASS (Čína).

Přístroj tak měří v každém bodu přesnou polohu, zaznamenanou v některém z používaných systémů (GPS, JTSK). Pro přesnou práci je nutné použití dvou přístrojů ve vzájemné komunikaci (jeden statický jako referenční), nebo připojení k serveru, který poskytuje korekční data.

\subsection{D Scaner}

Terestrické 3D skenovací systémy jako technologie umožňují bezkontaktní určování prostorových souřadnic, 3D modelování a vizualizaci složitých staveb a konstrukcí, podzemních prostor, libovolných terénů a dalších objektů s mimořádnou rychlostí, přesností, komplexností a bezpečností. Nasnímaný objekt může být pomocí softwaru zobrazen ve formě mračen bodů (point clouds), na jejichž základě může být vytvořen model objektu, který lze přenést do CAD systému.

Dokumentace místa dopravní nehody pomocí 3D scanneru představuje jednu $\mathrm{z}$ nejmodernějších metod dokumentace stop.

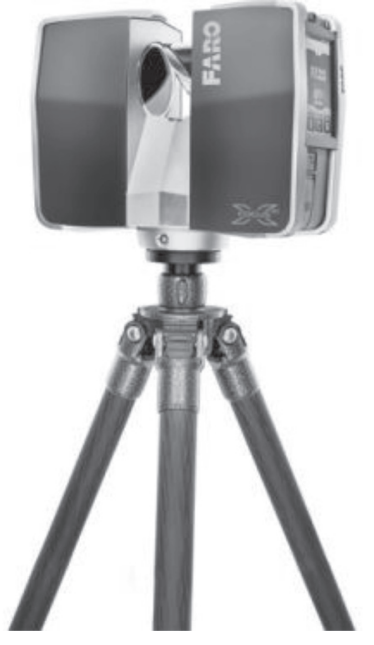

Obr. 8 Laserový 3D skener. Fig. 8 3D Laser Scanner.

Jednou z velkých výhod některých 3D scannerů je, že skenované místo je možné i nafotit a tím získat sférickou fotografii. [9]

\subsection{Fotografie}

Fotodokumentace patří k základním prostředkům dokumentace místa dopravní nehody. Kvalitně provedená fotodokumentace umožňuje následně dobré zpracování a zhodnocení dopravní nehody. Kromě běžně používaného šikmého fotografování vozovky pomocí ručního fotoaparátu, je možné využívat i jiné metody a zpracování fotografií. Jednou z rozšiřujících se metod je snímkování ze vzduchu. Pro tyto účely se nejčastěji využívají napríklad drony.

Jako metoda pro zpracování fotografií z místa dopravní nehody se nejčastěji využivá rektifikace, kdy se šikmo vyfotografovaná plocha vozovky transformuje na rovinný plánek místa dopravní nehody v půdorysu.

Fotografie je rovněž možné využít k získání 3D modelu.

\subsubsection{Letecký snímek - Dron}

Dokumentace nehody za pomoci leteckého snímkování je velice rychlou a přenou metodou jak zadokumentovat polohy vozidel a veškerých stop bez zkreslení. Tímto způsobem lze zaznamenat

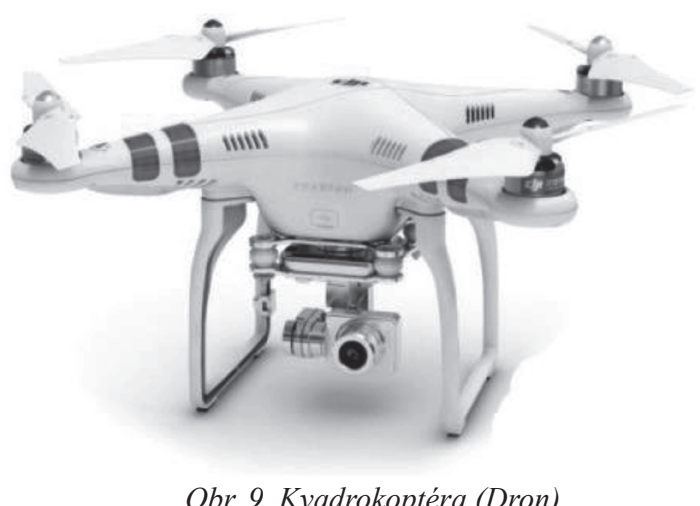

Fig. 9 Quadcopter (Dron). 


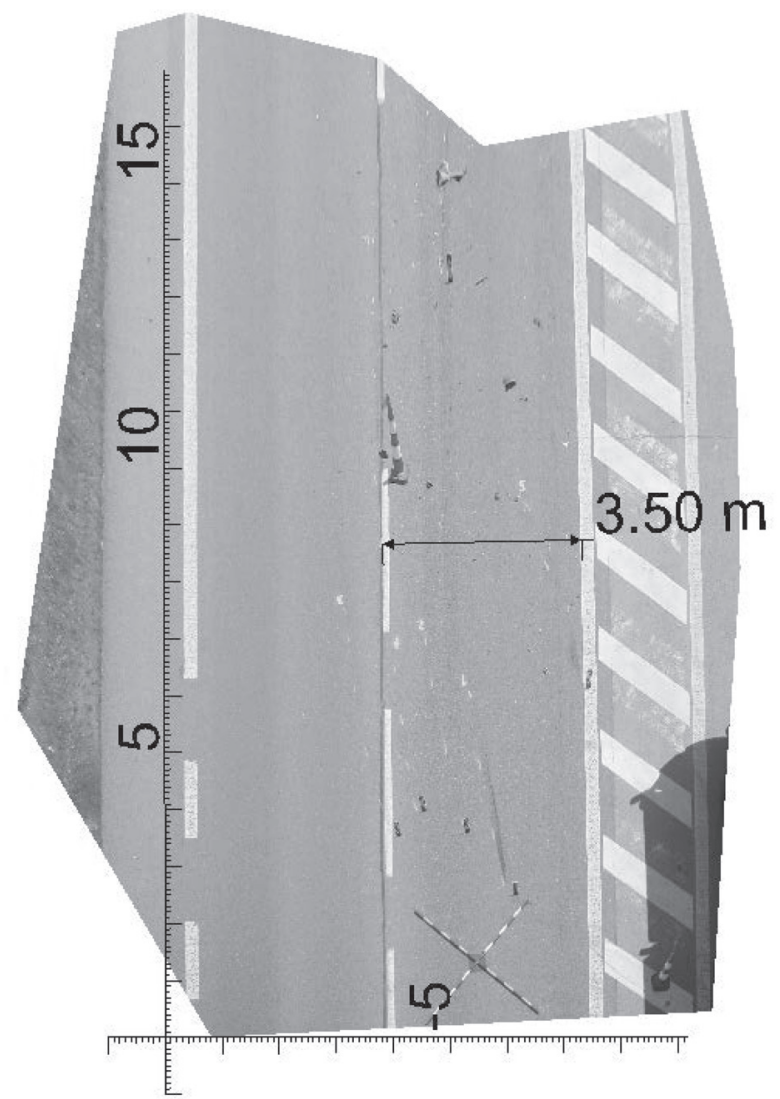

Obr. 10 Rektifikovaná fotografie mista dopravní nehody [10].

Fig. 10 Rectified photographs of the traffic accident scene [10].

rychle místo nehody, které je dlouhé i několik stovek metrů. Tento způsob má také své omezení. Hlavním technickým omezením je prostor nad místem dopravní nehody kde nesmí být žádné překážky (stromy, elektrické vedení, trolejové vedení, mosty), další omezení jsou právní, kdy s některými drony je třeba pilotní průkaz, povolení $\mathrm{k}$ letu a povolení k provozování leteckých služeb. Je rovněž třeba respektovat zákon o civilním letectví, který udává vzdálenosti od obytných budov, od osob apod., kde není možné létat.

\subsubsection{Rektifikace}

Fotogrammetrie je obor, zabývající se měřením rozměrů, určováním polohy předmětů a rekonstrukcí tvarů, zobrazených na fotografických snímcích. Obecně lze tedy říci, že se jedná o vědní obor zaměřený na zpracování informací z vyfotografovaných snímků. V posledních letech je tato metoda hojně využivána v oboru analýzy silničních nehod, zejména znalci v tomto oboru. Pořízené fotografické záběry z místa dopravní nehody, zejména polohu a rozměry jednotlivých stop, je možné díky této moderní metodě kdykoliv přezkoumat. Princip fotogrammetrie spočívá v pořízení fotografických snímků místa dopravní nehody, na těchto snímcích je spolu se stopami, které jsou předmětem rektifikace obrazu, umístěn tzv. rektifikační kř́žz. Jedná se o dvě na sebe kolmé úsečky o známé délce. Na základě těchto známých rozměrů rektifikačního kříže lze s pomocí počítačové podpory provést rektifikaci obrazu a zkoumat tak veškeré stopy, včetně jejich rozměrů, které jsou zachyceny $\mathrm{v}$ rektifikovaném obrazu $\mathrm{v}$ počítači, viz obr. 10.

V případě potřeby lze rektifikační kř́iž nahradit, a to tak, že se na komunikaci např. kř́́dou, sprejem, nebo jiným vhodným způsobem zakreslí čtyři body a změří se vzdálenosti mezi nimi (celkem tedy délky čtyř stran a nejméně jedné uhlopř́ičky). Další postup fotografické rektifikace už je shodný s postupem při využití rektifikačního kříže.

Tato metoda je vhodná obzvláště při dopravních nehodách většího rozsahu, kde se vyskytuje velké množství stop a předmětů. Další nespornou výhodou tohoto řešení je také to, že v prŕípadě užití fotografického záznamu není nutné zaměřit všechny rozměry

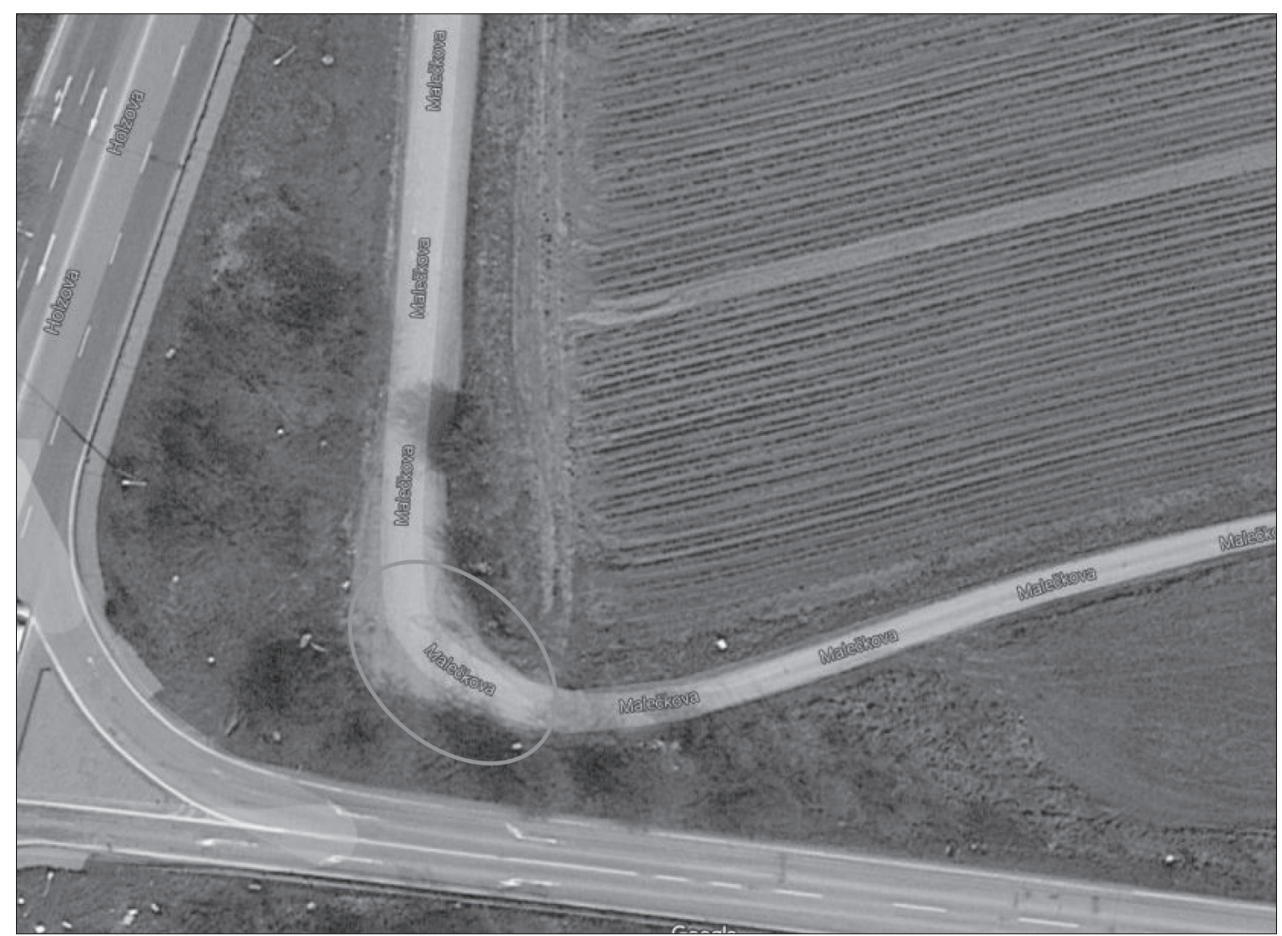

Obr. 11 Misto vzorové dopravní nehody [11].

Fig. 11 Instead exemplary traffic accident [11]. 


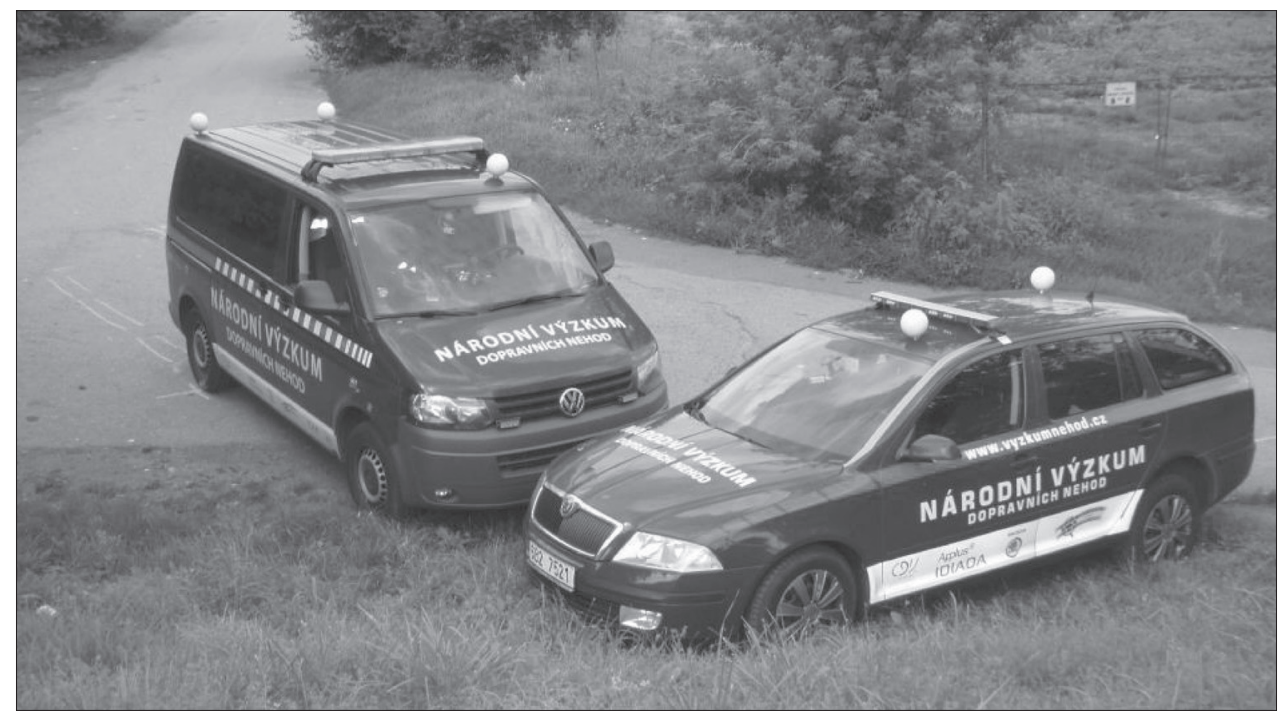

Obr. 12 Postaveni vozidel po dopravní nehodě [10].

Fig. 12 The status of vehicles after road accident [10].

a vzdálenosti stop od VBM, ale je možné tato měření provádět až dodatečně v počítači, což má pozitivní vliv na rychlost obnovení plynulosti provozu v místě dopravní nehody.

\subsubsection{D model z fotografii}

Díky počítačové podpoře je možné i dostatečného počtu digitálních fotografií docílit velmi podobného výsledku jako při použití 3D skeneru. Při fotografování prostoru dopravní nehody je nutné vytvořit několik stovek fotografií celého prostoru a jednotlivých vozidel ze všech potřebných úhlů. Následně lze využít bud' komerční SW (např. Photomodeler) nebo některý s produktů různých komunit, kdy fotografie zpracovává jejich server (např. Insight 3D).

\section{POPIS MODELOVÉHO MÍSTA DOPRAVNÍ NEHODY}

Pro vzájemné porovnání jednotlivých způsobů zaměření bylo z časových a bezpečnostních důvodů vytvořeno vzorové místo dopravní nehody. Prostor dopravní nehody se nacházel na ulici Malečkova v městské části Brno - Slatina, viz obr. 11. Jednalo se o místní komunikaci s velmi malou intenzitou provozu. Jako vzorová vozidla byla zvolena Škoda Octavia Combi a VW Caravelle. Jako střetová konfigurace byl volen boční excentrický střet, kdy vozidlo VW narazilo do pravé přední strany vozidla Škoda, viz obr. 12. Po nastavení vozidel do konečné polohy bylo prristoupeno $\mathrm{k}$ zaměření polohy vozidel a okolí s využitím jednotlivých metod zaměření.

\section{VÝSLEDKY}

\subsection{Měřičské kolečko}

Při zaměřování místa dopravní nehody měřičským kolečkem byla použita metoda trojúhelníkového měření v kombinaci s metodou pravoúhlého měření. Př́ícné a podélné sklony, jak samotné komunikace, tak i okolí, byly změřeny pomocí digitální vodováhy. Na obr. 12 je uveden plánek místa dopravní nehody vyhotovený v programu Virtual CRASH.

\subsection{Geodetická totální stanice}

Zaměření místa dopravní nehody bylo provedeno pomocí totální stanice Topcon. Při použití odrazného hranolu, lze při dobrých podmínkách měřit na vzdálenosti v řádu kilometrů. Při zaměřování místa dopravní nehody je tato vzdálenost dostačující, a to i pro dlouhé úseky např́íklad na dálnici nebo na rozhlehlých křrižovatkách. Při zaměřování místa dopravní nehody je potřeba vhodně zvolit místo ustanovení totální stanice, zejména, tak, aby ze zvoleného místa bylo vidět do všech důležitých míst a nevznikly místa zakrytého výhledu. Jedná se zejména o konečné polohy vozidel, stopy, př́ípadně části vozidel. V prrípadě složitosti terénu a výskytu pevných překážek je možné provést tzv. přestaničení. Totální stanice se přemístí na jiné definované místo, které bylo předem změřeno a ze kterého lze zaměřit i místa která předtím nebylo možno zaměřit.

Po provedení měření na místě dopravní nehody se naměřená data zpracují. Totální stanice umožňuje ukládat data ve většině běžně užívaných formátech, např́íklad *.dxf, *.txt, atd. Naměřená data je nutné transformovat pomocí vhodného konvertoru tak, aby vznikl odpovídající textový dokument. S ním lze následně pracovat a vytvořit soubor ve formátu *.dxf, který je možné jako polygon naimportovat do programu PC Crash nebo Virtual Crash. Polygon nahraný do simulačního programu je možné dle potřeby dále modifikovat, tak aby odpovídal potřebám pro vlastní analýzu nehodového děje (obr. 14).

\subsection{GNSS přijímač}

Pro zaměření místa DN byl použit GNSS přijímač Trimble X91+ s kontrolérem Getac LT30. Jedná se o 220 kanálový přijímač pracující s družicovými systémy GPS, Glonas, Compas a do budoucna i s Evropským systémem Galileo. Pro upřesnění pozice je využíváno korekčních dat poskytovaných prostřednictvím permanentních stanic GNSS, které spravuje CZEPOS (obr. 15). 


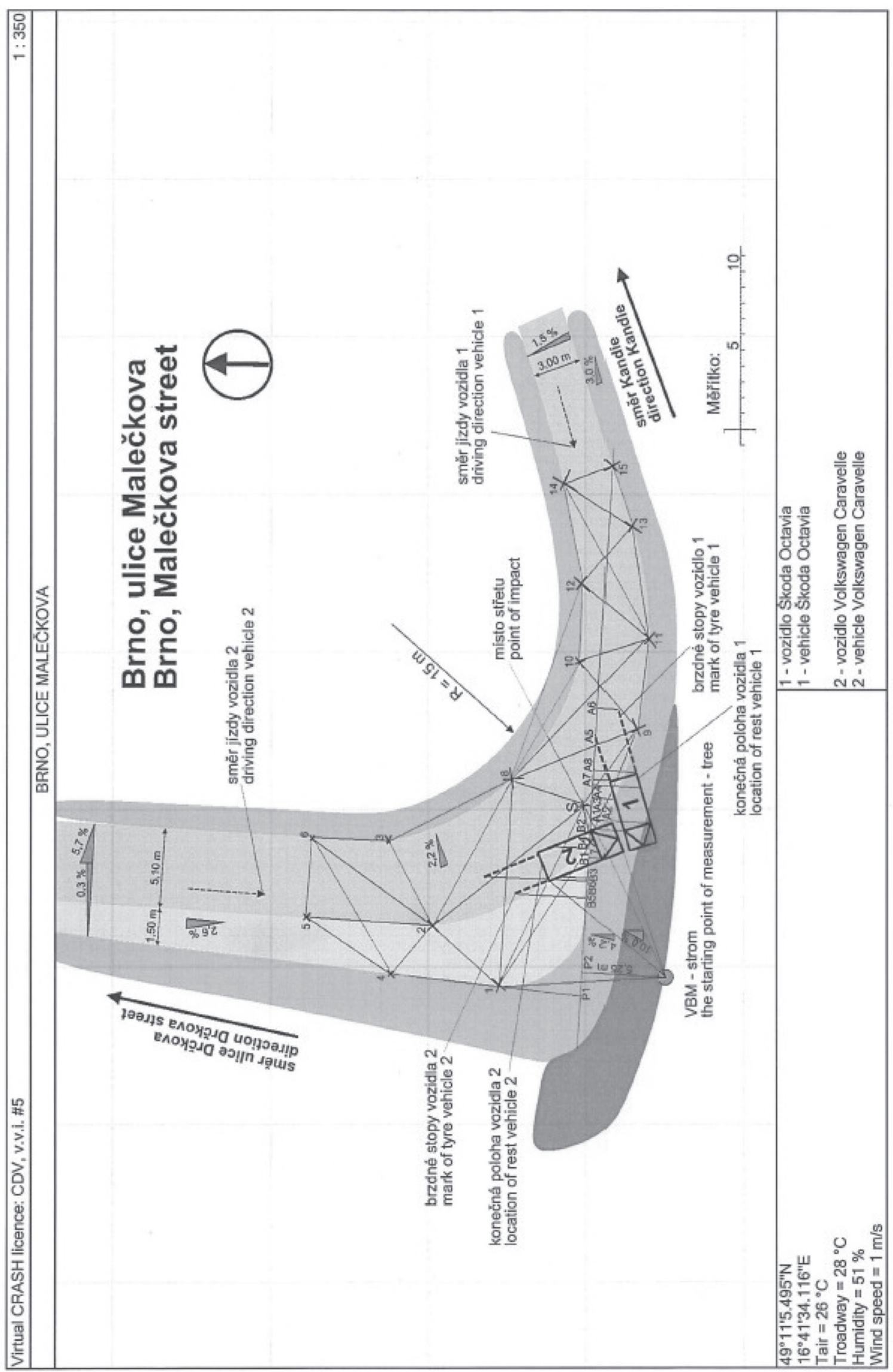

Obr. 13 Nakreslený plánek místa dopravní nehody na základě ručního měření [10].

Fig. 13 Drawn map location of traffic accidents based on the manual measurement [10]. 


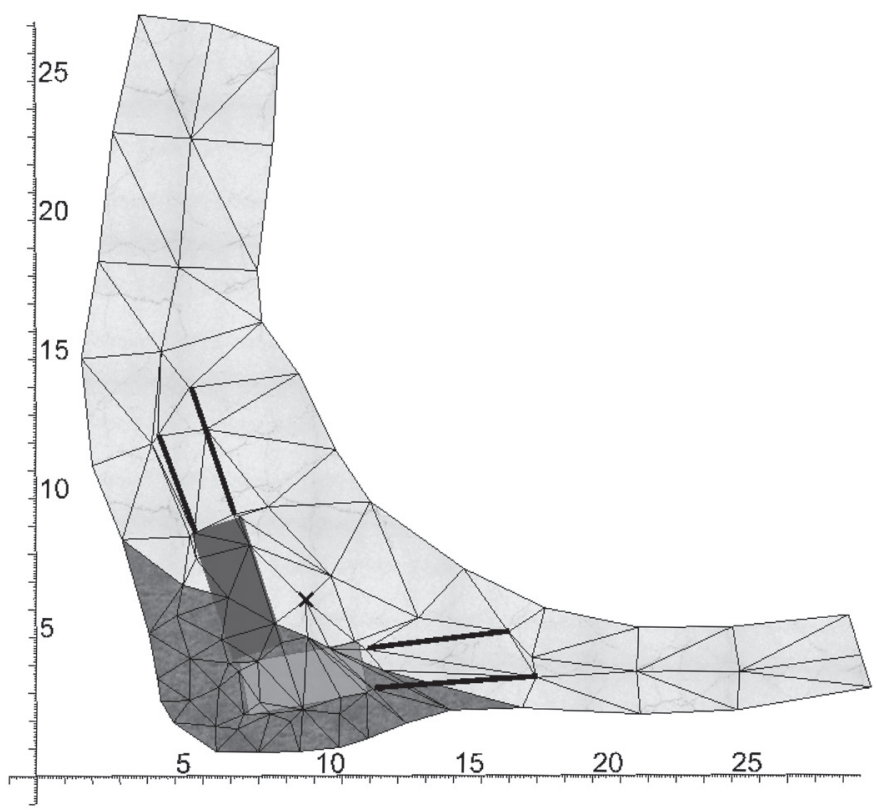

Obr. 14 Plánek dopravni nehody vytvořený na základě zaměreni pomocí totálni stanice [10]. Fig. 14 Plan a traffic accident created on the basis of the focus by using the total station [10].

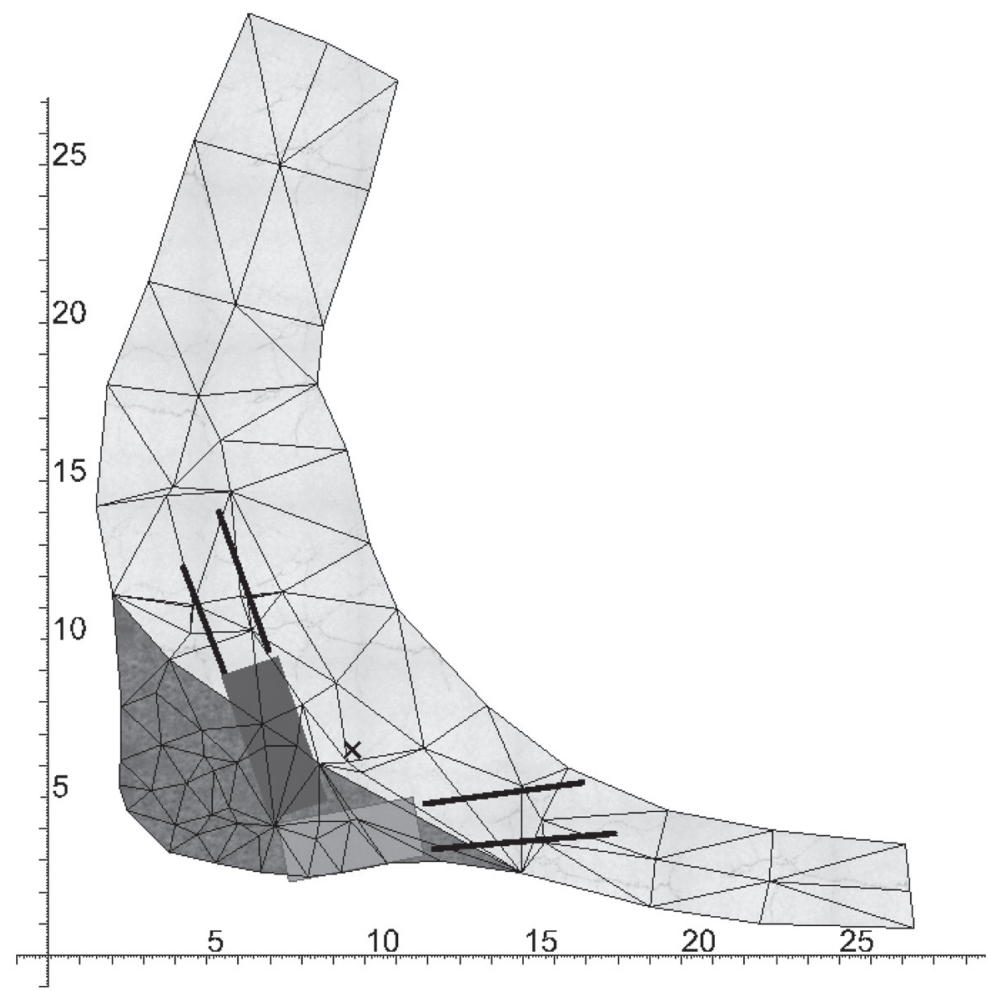

Obr. 15 Plánek dopravní nehody vytvořený na základě zaměřní pomocí GNSS [10].

Fig. 15 Plan created a traffic accident on the merits of using GNSS [10].

Na obr. 16 je uvedeno porovnání polygonu zaměřeného pomocí geodetické totální stanice a GNSS přijímače. Šedý polygon je vytvořen $\mathrm{z}$ dat získaných pomocí totální stanice, bílý polygon pak pomocí GNSS přijímače. Vzájemným porovnáním je vidět, že se oba polygony téměř shodují. Vzájemné zanedbatelné odchylky vykazují pouze několik výškových souřadnic.

\subsection{D scanner}

Pro skenování místa dopravní nehody byl použit panoramatický scanner Faro Focus 3D. Tento scanner pracuje na bázi vyzařování bodového laserového paprsku. Paprsek dopadá na otáčející se kosé zrcadlo, které jej láme pod úhlem $90^{\circ}$. Tímto je zajišstěno skenování prostoru ve vertikálním směru. Aby bylo možno snímat prostor 


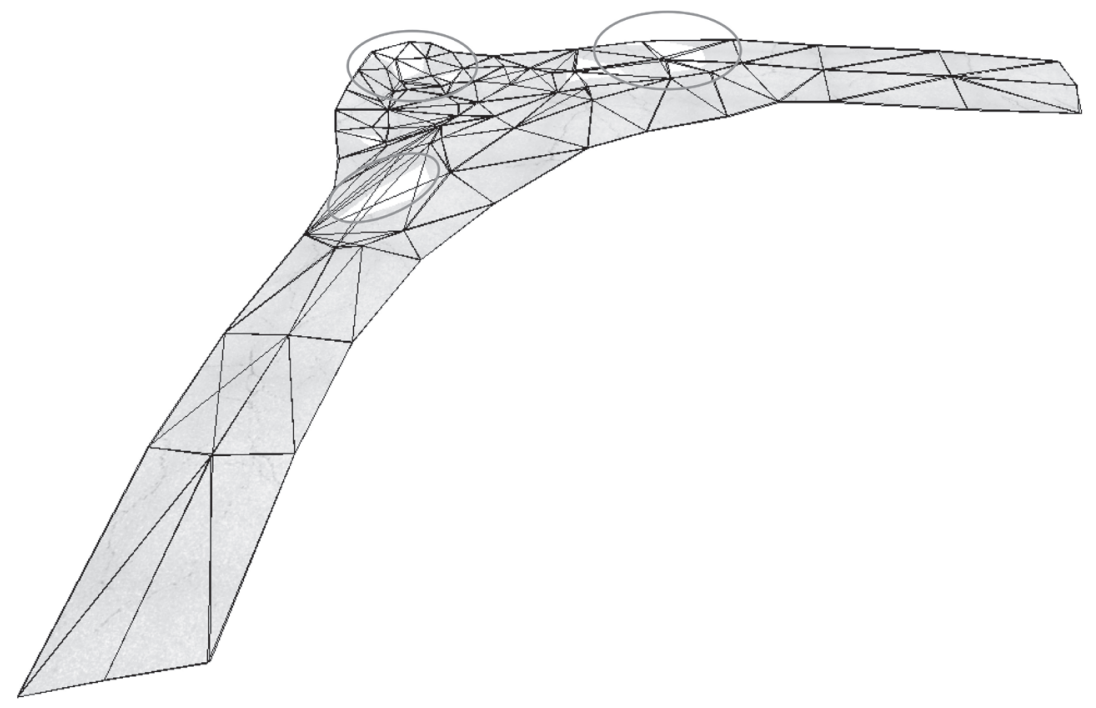

Obr. 16 Porovnání polygonů [10].

Fig. 16 Comparison of polygons [10].

taktéž v horizontálním směru, otáčí se celý skener na podstavci kolem vlastní svislé osy. Systém komunikuje s počítačem přes sít’ové rozhraní Ethernet, a to drátově i bezdrátově, má však vestavěný i vlastní dotykový displej pro snadné ovládání bez PC a pamětovou kartu SDHC pro ukládání dat. Systém má integrovanou baterii, kterou je možné $\mathrm{v}$ př́ípadě potřeby velmi snadno vyměnit za nabitou. Skener je vybaven integrovaným fotoaparátem, který má rozlišení až 70 megapixel, takže je schopen naskenované místo také nafotit. Díky tomu je následně možné složený a upravený sken obarvit, technicky dojde k obarvení jednotlivých bodů. Skener využivá pro měření délek fázový dálkoměr s rozsahem měření $0,6 \mathrm{~m}$ až $120 \mathrm{~m}$ a s přesností do $2 \mathrm{~mm}$ je schopen skenovat rychlostí až
976000 bodů za sekundu v zorném poli $360^{\circ}$ horizontálně a $305^{\circ}$ vertikálně. Rozlišení je stejné pro obě osy $0,009^{\circ}$. Dále je skener vybaven dvouosým kompenzátorem, altimetrem a kompasem. Operační teplota je od $+5{ }^{\circ} \mathrm{C}$ do $+40{ }^{\circ} \mathrm{C}$ a udávaná výdrž baterie cca 5 hod. Rozměry skeneru jsou $240 \times 200 \times 100 \mathrm{~mm}$ s váhou $5 \mathrm{~kg}$.

Výstup z 3D skeneru dává ucelý přehled o místě dopravní nehody. Ve vytvořeném polygonu je možné si odměřovat požadované rozměry a místo si prohlédnout $\mathrm{z}$ různých úhlů (obr. 17, 18).

\subsection{Fotodokumentace}

Z místa dopravní nehody byla pořízena fotodokumentace digitálním fotoaparátem. Při zhotovování fotodokumentace bylo postupováno

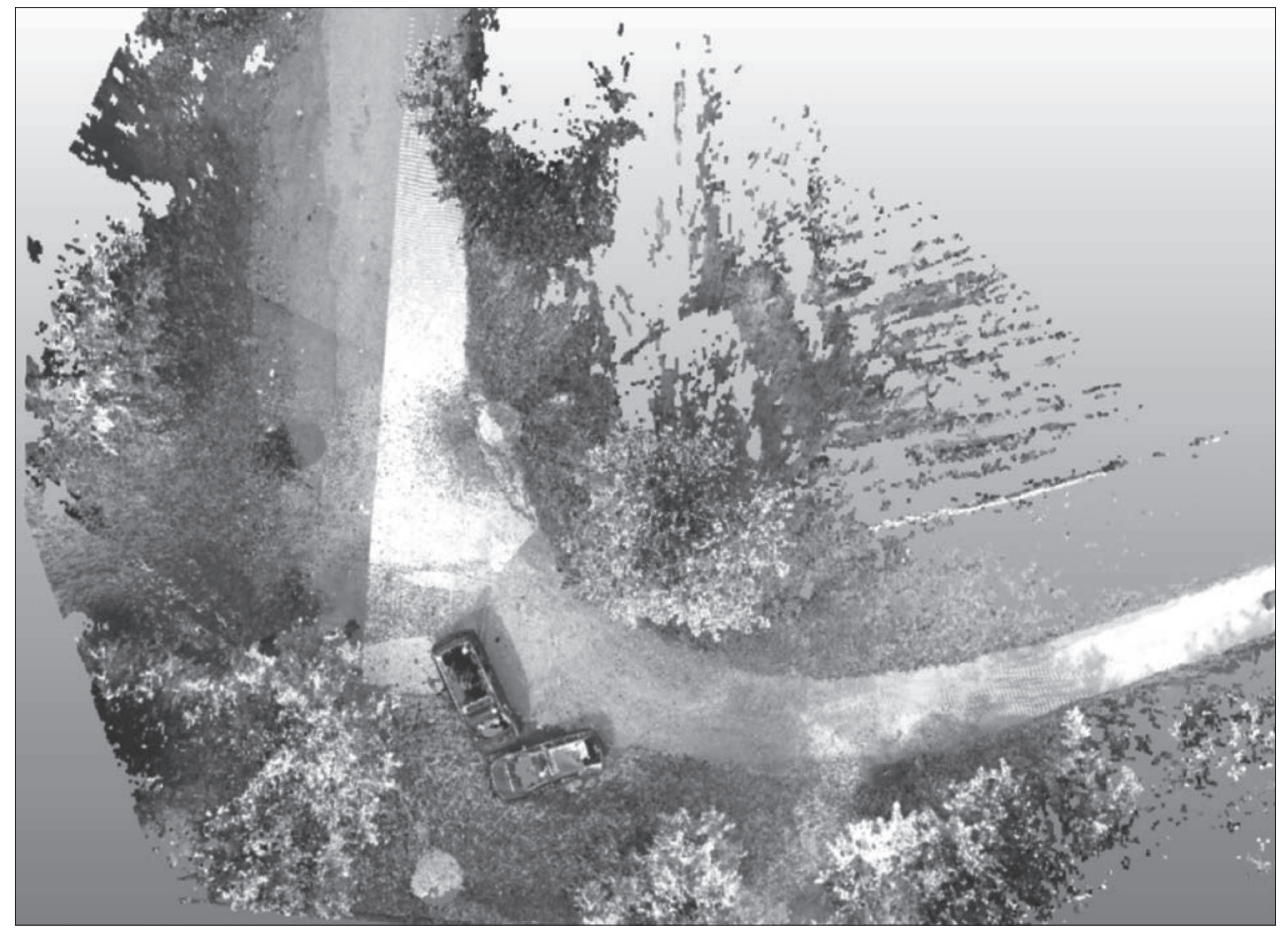

Obr. 17 Ortofotomapa vytvořená pomocí 3D scanneru [10].

Fig. 17 Ortofotomapa vytvořená pomocí 3D scanneru [10]. 


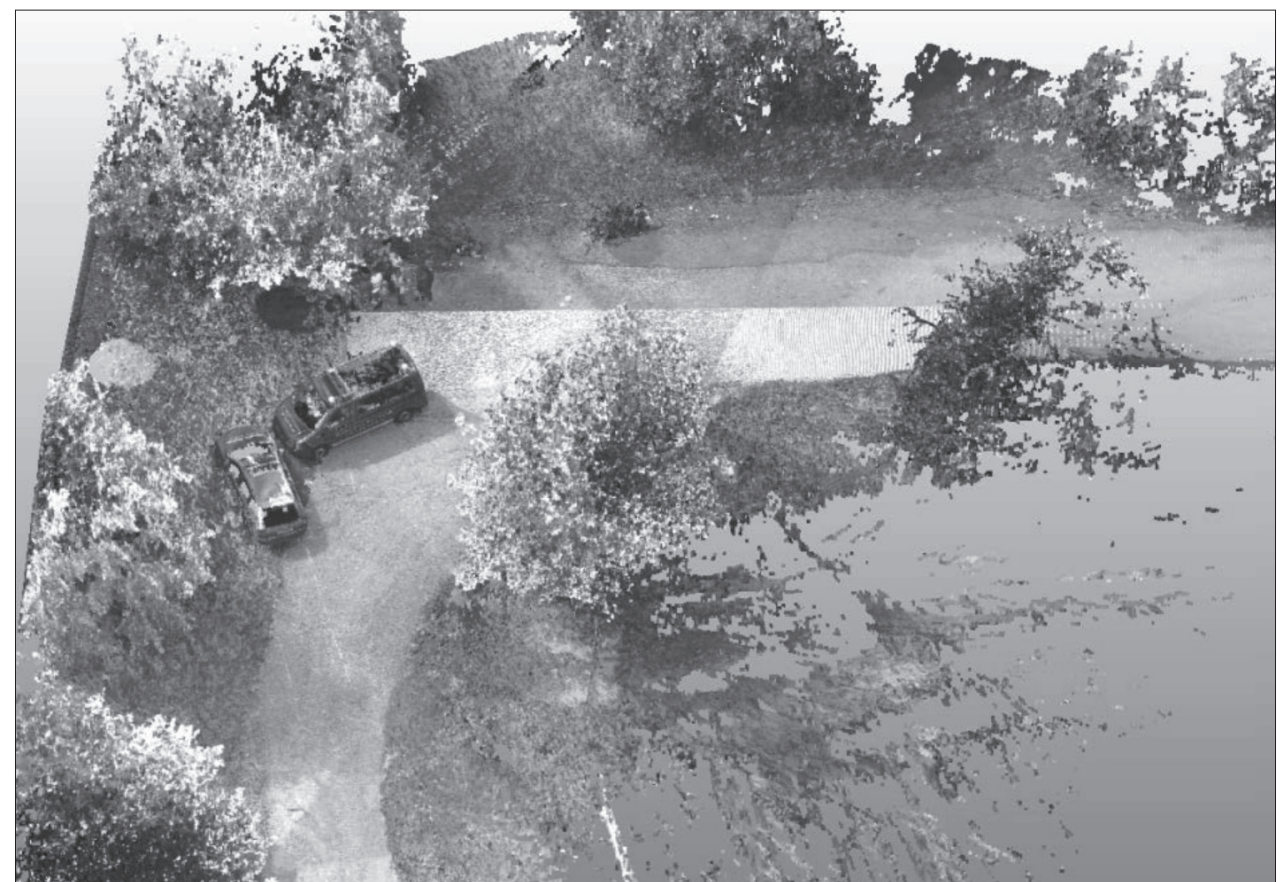

Obr. 18 Místo dopravní nehody tvořené obarveným mračnem bodů [10].

Fig. 18 Instead of traffic accidents dyed formed a cloud of points [10].

od snímků celkových, přes polocelkové, polodetailní až k detailním. Výhodné je rovněž pořízení snímků z nadhledu.

\subsubsection{Letecký snímek - dron}

Další z možností dokumentace místa dopravní nehody se s rozvojem nových technologií stává využití dálkově ovládaných bezpilotních prostředků - nejčastěji multikoptér, které jsou dnes známé pod pojmem dron. Jedná se zejména o možnost pořízení fotografických snímku místa dopravní nehody bezprostředně po nehodě, případně je možné tuto fotodokumentaci pořídit i s časovým odstupem od dopravní nehody, v takovém případě je ale obvykle nutné zvýraznit stopy, případně konečné polohy vozidel.

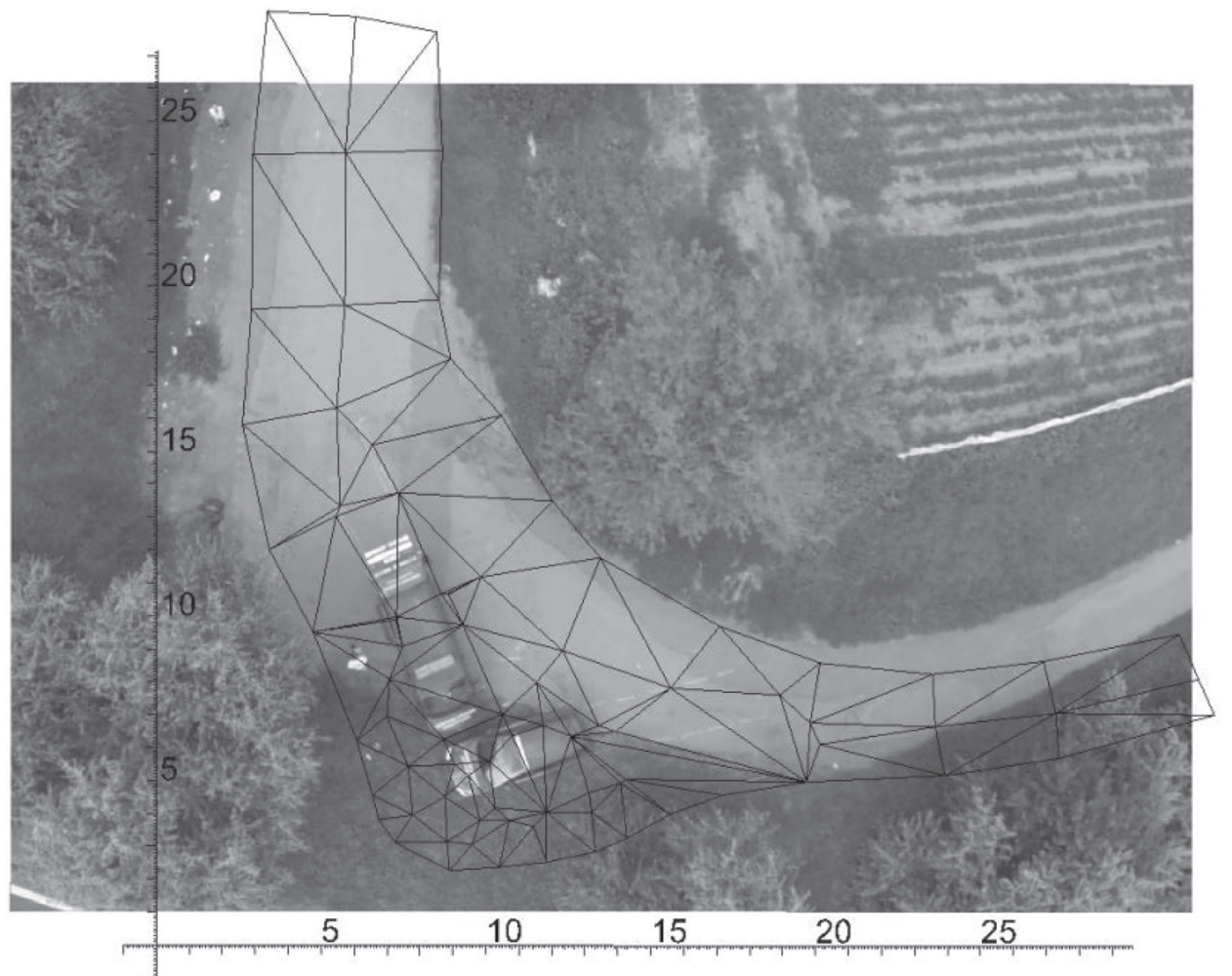

Obr. 19 Místo dopravní nehody - letecký snímek [10].

Fig. 19 Instead of traffic accidents - Aerial shot [10]. 


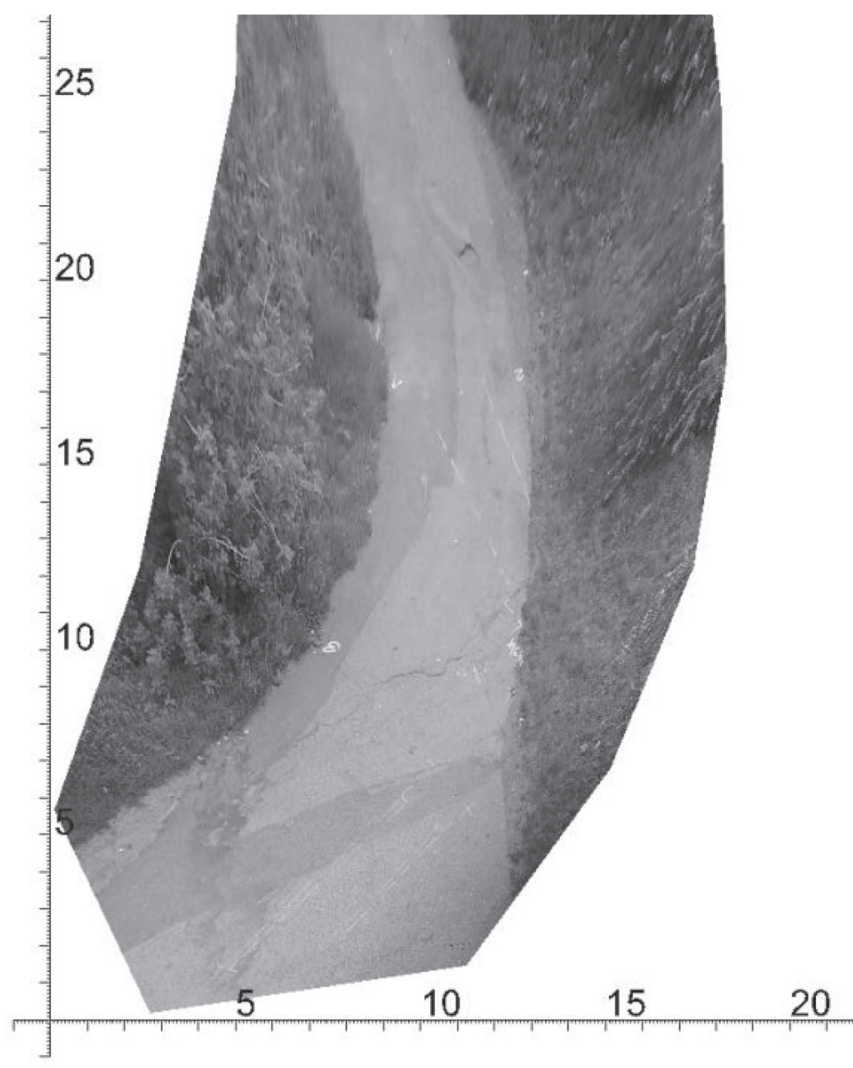

Obr. 20 Misto dopravní nehody - rektifikovaná fotografie [10]. Fig. 20 Instead of traffic accidents - rectified photo [10].

Pro získání leteckého snímku místa dopravní nehody byl použit model kvadrokoptéry, na kterém byla na spodní části připevněna kamera. Poté byl z video záznamu vystřižen konkrétní snímek, a ten lze použít v kombinaci s polygonem jako podklad pro simulaci dopravní nehody. Letecký snímek je neocenitelný ve chvíli, kdy jsou na místě dopravní nehody desítky brzdných a dřecích stop a desítky částí vozidel, které by se bez snímku museli každý zaměřovat zvlášt'. Na obr. 19 je uvedeno porovnání polygonu zaměřeného pomocí totální stanice a fotografie pořízené $\mathrm{z}$ dronu. Z porovnání je patrné, že polygon s fotografií v měřítku nejsou ve shodě. Tato nepřesnost je dána vlastností fotoaparátu na dronu, který má určité zkreslení dané vlastností čočky kamery (jedná se o tzv. „rybí oko“) a díky absenci stabilizační plošiny není fotoaparát přesně kolmo nad povrchem. Toto lze odstranit použitím více snímků, či použitím lépe vybavené verze dronu.

\subsection{Rektifikace}

Princip digitální rektifikace fotografií spočívá v tom, že se transformuje šikmo vyfotografovaná plocha vozovky na rovinný plánek místa dopravní nehody v půdorysu, který je relativně přesný a umožňuje v konkrétním měřítku zobrazit veškeré vzdálenosti. Nesporná výhoda této metody spočívá $\mathrm{v}$ možnosti dodatečného změření vzdálenosti nebo délky stopy př́imo na rektifikované fotografii. Je možno provést i vyhodnocení z více snímků, které jsou navzájem propojeny přes dvojice bodů, což umožňuje dokumentovat i poměrně rozlehlá místa dopravní nehody. [8]

\section{ZÁVĚR}

Vzájemné porovnání jednotlivých metod zaměření místa dopravní nehody je uvedeno v tab. 1. Porovnání je provedeno z pohledu času potřebného pro samotné zaměření místa dopravní nehody, pro zpracování naměřených dat a vytvoření plánku nebo polygonu, přibližných nákladů na pořízení potřebného vybavení a orientační doba nutná pro zaškolení. Čas potřebný pro měření na místě dopravní nehody je počítán včetně doby nutné pro př́ípravu, ev. sestavení a následně složení použitého př́istroje nebo zařízení.

Tab. 1 Porovnáni jednotlivých metod zaměření.

Tab. 1 Comparison of different methods of measurement.

\begin{tabular}{|c|c|c|c|c|c|c|}
\hline & Měřící kolečko & GNSS přijímač & Totální stanice & 3D skener & Rektifikace & Dron \\
\hline $\begin{array}{l}\text { Měření na místě } \\
\text { dopravní nehody }\end{array}$ & $45 \mathrm{~min}$ & $30 \mathrm{~min}$ & $30 \mathrm{~min}$ & $45 \mathrm{~min}$ & $10 \mathrm{~min}$ & $10 \mathrm{~min}$ \\
\hline $\begin{array}{l}\text { Orientační doba } \\
\text { zpracování dat }\end{array}$ & $50 \mathrm{~min}$ & $15 \mathrm{~min}$ & $15 \mathrm{~min}$ & $60 \mathrm{~min}$ & $10 \mathrm{~min}$ & $5 \mathrm{~min}$ \\
\hline $\begin{array}{l}\text { Orientační } \\
\text { pořizovací cena } \\
\text { zařízení }\end{array}$ & 5 tis. & 150 tis. & 100 tis. & 1 mil. & $\begin{array}{l}\text { od } 1 \text { tis. HW } \\
\text { a } \\
\text { desetitisíce SW } \\
\end{array}$ & $\begin{array}{l}30 \text { tis. HW } \\
\text { a } \\
\text { desetitisíce SW } \\
\end{array}$ \\
\hline $\begin{array}{l}\text { Orientační doba } \\
\text { zaškolení }\end{array}$ & hodiny & hodiny & hodiny & dny & hodiny & týdny \\
\hline Výhody & $\begin{array}{l}\text { Jednoduché, } \\
\text { levné }\end{array}$ & $\begin{array}{l}\text { Vysoká přesnost, } \\
\text { obsluha jednou } \\
\text { osobou }\end{array}$ & Vysoká přesnost & $\begin{array}{l}\text { Věrný záznam } \\
\text { místa, včetně } \\
\text { barev }\end{array}$ & $\begin{array}{l}\text { Rychlost } \\
\text { a nenáročnost } \\
\text { na zaškolení }\end{array}$ & $\begin{array}{l}\text { Rychlost } \\
\text { zaměření }\end{array}$ \\
\hline Nevýhody & $\begin{array}{l}\text { Oproti ostatním } \\
\text { uvedeným } \\
\text { metodám menší } \\
\text { přesnost }\end{array}$ & $\begin{array}{l}\text { Nemožnost } \\
\text { využití v místech } \\
\text { bez výhledu } \\
\text { na družice nebo } \\
\text { s obtížným } \\
\text { výhledem }\end{array}$ & $\begin{array}{l}\text { Nutnost obsluhy } \\
\text { dvou osob (mimo } \\
\text { robotizované } \\
\text { TS), nutný } \\
\text { přímý výhled } \\
\text { mezi stanicí } \\
\text { a odrazovým } \\
\text { terčem }\end{array}$ & $\begin{array}{l}\text { Vysoké } \\
\text { pořizovací } \\
\text { náklady, delší } \\
\text { doba zaměření }\end{array}$ & $\begin{array}{l}\text { Částečné omezení } \\
\text { při použití } \\
\text { na rozlehlých } \\
\text { a členitých } \\
\text { místech DN }\end{array}$ & $\begin{array}{l}\text { Omezení letu nad } \\
\text { některými místy }\end{array}$ \\
\hline
\end{tabular}


Z výše uvedené tabulky je patrné, že z pohledu časové náročnosti na zaměření i následné zpracování vychází nejlépe rektifikace fotografií. Tato metoda je nenáročná na pořízení $\mathrm{HW}$, v zásadě stačí mobilní telefon s lepším fotoaparátem nebo kompaktní fotoaparát. Vyšší nároky jsou však na rektifikační SW. Zde se již můžeme bavit o nákladech v řádu desetitisíců. $\mathrm{K}$ dispozici jsou i free programy, jejich používání je však omezené a nemusí umožnit některé požadované funkce. Časové požadavky na zaškolení obsluhy jsou však malé, $v$ řádu hodin.

Relativně málo času vyžaduje i zaměření místa DN pomocí dronu. Snímky z dronu je možné upravit převedením do vhodného měřítka a poskládáním a tím získat vhodný podklad pro následnou analýzu DN. Získaný snímek je však stejně jako u první uvedené metody dvojrozměrný. Je tedy pod něj potřeba vytvořit polygon. Nespornou výhodou je věrné zachycení stop na místě DN. Výhodou pořízení snímků pomocí dronu je kvalitní přehled místa DN (i bez rektifikace téměř půdorysný náhled) a rychlé nasnímání i rozlehlého místa. Nevýhodou je problematika nafocení místa DN za tmy, za špatného počasí (silný vítr, déšst', sněžení atd.) a legislativní omezení. Podle současné právní úpravy nelze s dronem létat nad osobami, nad vozovkami a v jejich bezprostřední blízkosti a bez souhlasu majitele nad soukromými pozemky.

Časově náročnější je využití měřícího kolečka. Tento způsob zaměření je však jednoduchý, levný a nenáročný na zaškolení. Nevýhodou je, že zde může vznikat a v některých př́ípadech i vzniká značná nepřesnost. Zejména v porovnání s pokročilejšími metodami zaměření (totální stanice, GNSS atd.).

Časově náročné je taky použití 3D skeneru. Je však potřeba říci, že při zaměření místa dopravní nehody pomocí skeneru získáme, na rozdíl od zaměření měřícím kolečkem, trojrozměrný model - polygon. V případě následně prováděné simulace pomocí specializovaného softwaru již nemusíme potřebný polygon vytvářet, ale stačí ho jen naimportovat. Skener také dokáže vytvořit polygon s detailním zobrazením stop na prostředí. Naskenované mračno bodů se obarví a vyniknou tak i jiné, než plastické stopy. Avšak časová náročnost na zaměření, následné zpracování a také zejména finanční náročnost zapovídají v současné době rozšiřrení této technologie ve větším měřítku. Využití 3D skeneru pro dokumentaci dopravních nehod přináší řadu výhod a v budoucnu se jistě stane běžně užívanou metodou.

Zaměření pomocí GNSS nebo totální stanice je v porovnání $\mathrm{s}$ využitím skeneru časově méně náročné. Výstupem jsou prostorové body, ze kterých je možné vytvořit polygon. Tento způsob zaměření je velmi přesný a rychlý. Sám o sobě však neumožňuje obarvení polygonu, tak jak to umožňuje skener. Jako ideální varianta pro získání co nejdokonalejšího plánku s podrobnými detaily stop na prostředí se jeví využití totální stanice, res. GNSS přijímače pro vytvoření prostorového polygonu a následné překrytí fotografií z dronu, nebo rektifikovanou fotografií z fotoaparátu.

Tento článek byl vytvořen za finanční podpory Ministerstva školství, mládeže a tělovýchovy v rámci programu Národní program udržitelnosti I, projektu Dopravní VaV centrum (LO1610) na výzkumné infrastruktuře pořízené z Operačního programu Výzkum a vývoj pro inovace (CZ.1.05/2.1.00/03.0064).

\section{LITERATURA}

[1] BRADÁČ, A. a kol.: Soudní inženýrství. CERM, Brno, 1997, 140 s. ISBN 80-7204-057-X.

[2] ŘÍHA, J. Moderní prístrojová technika. [online] Praha 2014 [cit. 13. 08. 2018]. Dostupné z: http://spszem.cz/

[3] PORADA, V. Vyhledávání a zajištování kriminalistických stop na místě činu. Soudní inženýrství. 2004, 15(6). Dostupné z: http:// www.sinz.cz/archiv/docs/si-2004-06-312-328.pdf

[4] CHMELÍK, J. a kol. Dopravní nehody. Plzeň: Nakladatelství Aleš Čeněk, 2009, 540 s. ISBN 978-80-7380-211-0.

[5] CHMELÍK, J. Vyšetřování silničnich dopravnich nehod. Ministerstvo vnitra ČR, odbor person. práce a vzdělávání PČR, Úřad vyšetřování pro českou republiku, Praha, 1998.

[6] RÁBEK, V. Vybrané postupy analýzy dopravnich nehod. Edis vydavatelstvo Žilinskej university, Olomouc, 2009, 199 s. VPRA-SCP-2009-06-02.

[7] TOKAŘ, S., STÁŇA, I., BILÍK, M. Porovnání možnosti zaměření místa dopravní nehody. IN: ExFoS 2016, XXV. mezinárodní vědecká konference Soudního inženýrství 29. a 30. ledna 2016, ÚSI VUT Brno, Brno, 2016, s. 146-158.

[8] STÁŇA, I., TOKAŘ, S., BUCSUHÁZY, K., BILÍK, M. Comparison of Utilization of Conventional and Advanced Methods for Traffic Accidents Scene Documentation in the Czech Republic. In: Procedia Engineering, 2017, 187(C), s. 471-476. ISSN 1877-7058.

[9] BULKA, D., CURYLO, J., WOLAK, S., ŚLEZIAK, M., PIOTR, Ś. Techniki obrazovania 2D/3D na miejscu wypadku drogowego. In: XV Konferencja Naukowa „Problemy Rekonstrukcji Wypadków Drogowych“. 28. až 30. zář́ 2017, Zakład Badania Wypadków Drogowych Instytutu Ekspertyz Sadowych, Zakopane, 2017, s. 23-48.

[10] Archiv CDV.

[11] Google maps. [online], [cit. 13. 08. 2018]. Dostupné z: http:// www.google.cz/maps

\section{Správná citace:}

MOTL, J., RÜCKER, J., KAFOŇKOVÁ, J., BRADÁČ, A. Metody dokumentace místa dopravní nehody. Soudní inženýrství, 2018, 29(4), 25-36. DOI: http://dx.doi.org./10.13164/SI.2018.4.25. ISSN 1211-443X. 